\title{
To resume or not to resume: Some remarks on 'resumption' in left dislocation constructions in Polish, and its relevance for Biblical Hebrew
}

\author{
Alexander Andrason \\ Department of African Languages, Stellenbosch University, South Africa \\ E-mail: andrason@sun.ac.za
}

\begin{abstract}
The present paper analyzes the use of resumption in LD constructions in Polish. The evidence indicates that, in various cases, resumption is not obligatory in Polish. In fact, Polish LD constructions omit resumptive elements more often than they employ them. The absence of resumption is a part of a more a general phenomenon in Polish - the gradient nature of LD constructions ranging from more canonical (approximating the crosslinguistic prototype) to less canonical (more distant from the prototype), and their relationship to fronting. This article provides further evidence for the facultative status of resumption in the crosslinguistic LD category, and for the universal, formal and functional, relationship between LD and fronting.
\end{abstract}

Keywords: Polish; left dislocation; resumption; fronting

\section{Introduction}

One of the objectives of the workshop on L(eft) D(islocation) held at Stellenbosch University in September 2015 was to analyze properties that are crosslinguistically typical of the LD construction, focusing on their relevance for B(iblical) $\mathrm{H}(\mathrm{ebrew})$. Several characteristics were identified, e.g. the marking of the dislocate by a pausal intonation and the absolute case (casus pendens), its extra-clausal position overtly indicated by the presence of clause-boundary markers separating the dislocate and the matrix clause, and the use of resumptive elements in the matrix clause that are co-indexed with the dislocate. During the workshop and, especially, considering recent debates on information structure which polarized $\mathrm{BH}$ scholarship, it became clear that, among all such properties, the issue of resumption is particularly significant (van der Merwe and Naudé forthcoming). This issue may be summarized in the following question: Is resumption a necessary characteristic of LD in Biblical Hebrew? One group of scholars argues that in Biblical Hebrew resumption is compulsory for LD to occur. In cases where resumption is absent, a given construction is not an example of LD. Instead, a new category is postulated, namely 'extreme topicalization' (Holmstedt 2014). The other group holds that resumption does not constitute a necessary condition of LD in Biblical Hebrew and thus, there are cases of LD in which resumption is absent. Grounding their ideas in prototype theory and family resemblance, these scholars view resumption as a characteristic of an idealized canonical LD 
structure, which may, but does not have to, be instantiated in actual languages. In fact, there are languages where resumption is not required or even where its absence is preferable (Andrason and Karani forthcoming). This is possible because the prototype and its instantiations form family-resemblance relationships. That is, actual LD constructions are related to the prototype by sharing some features but not necessarily all of them - their compliance with the prototype may be total or partial. Thus, LD is a radial category (Westbury 2014, 2015).

The present paper aims to contribute to this debate by analyzing the use of resumption in LD constructions in Polish. The article will be organized in the following manner. In section 2, I will discuss the properties of LD in Polish, focusing on the status of resumption, as either obligatory or facultative. Two types of evidence will be used. First, I will draw on the competence of native speakers interviewed for this study (section 2.1). Subsequently, I will analyze Polish translations of the LD examples in $\mathrm{BH}$, which constituted the starting point of the workshop. In section 3, I will discuss the relevance of the findings for the broader relationship between LD and Fronting. Lastly, in Section 4, main conclusions will be drawn, and their contribution to the issue of LD in BH scholarship will be explained.

\section{Evidence - Left Dislocation in Polish}

\subsection{Competence-based evidence}

I will begin the analysis of LD in Polish by discussing the properties of this construction that can be derived from the competence of native speakers. This competence study builds on examples that were provided by three native speakers of Polish. Whenever it is possible, I will relate this evidence to the most significant studies dedicated to the question of LD and resumption in Polish.

Two main types of LD can be distinguished in Polish: a class of 'as-for' LD constructions and constructions which will be referred to as 'simple' LD. The former type consists of a dislocated element headed by expressions equivalent to as for (and its varieties) in English (e.g. co do, jeśli chodzi o, jeśli idzie o, etc.; Duszak 1984; Bondaruk 2014: 71; see examples 1.a-b). ${ }^{1}$ In contrast, in the latter type, the dislocate element fails to be preceded by any specific introductory expression $(2 . a-c){ }^{2}$

The two LD constructions exhibit a similar behavior. In both types, the dislocate is placed in the left periphery, outside the matrix clause. In the two structures, and especially in speech, the so-called "caesura" particle to is commonly used to separate the dislocate from the matrix clause (Duszak 1984). This usage is granted by the fact that this particle often (albeit not always) demarcates the topic of a proposition from the comment or the rheme (Duszak 1984; Huszcza 1980, 1981). ${ }^{3}$ The two constructions are regularly characterized by a pausal intonation,

\footnotetext{
${ }^{1}$ There is a long-standing debate as to whether 'as-for' constructions are, cross-linguistically, LD or not (Villalba 2000; Tizon-Couto 2012).

${ }^{2}$ Of course, the dislocate can follow other items, for instance conjunctions (e.g. $i$ 'and') or complementizers (że 'that').

3 This particle is diachronically related to the pronoun to 'it, this' (Huszcza 1980, 1981; Duszak 1984; Tajsner 2015). It is also defined as an "identificational demonstrative" (i.e. a resumptive pronoun identifying a topic; Rutkowski 2006) or as a predicate head (Tajsner 2015: 58; see also Bondaruk 2013). For a detailed analysis of to consult Rutkowski (2006); Citko (2008); Bondaruk (2013); Tajsner (2015 and forthcoming).
} 
which is indicated in written texts by a comma. ${ }^{4}$ Lastly, both forms may also exhibit resumption (Bondaruk 2014: 71). As is typical crosslinguistically, this resumptive pronoun identifies a dislocated element and specifies its role in the matrix (Tajsner 2015: 33, 41, 58). ${ }^{5}$ The main difference between the two types concerns the grammatical case of the dislocate. The 'as-for' $L D$ requires the dislocate to be in the genitive case or any other case imposed by an introductory item: a preposition or a verb (1.a-b). In the 'simple' $L D$, the dislocate may appear in the nominative which acts as the casus pendens (2.a-b). However, the dislocate can also make use of a morphological case that coincides with the case of the resumptive element found in the matrix clause. Accordingly, the role of the dislocate may (to a certain degree) be specified by its own form.

\begin{tabular}{|c|c|c|c|c|c|c|c|}
\hline \multirow[t]{2}{*}{ a. } & $\begin{array}{l}\text { Co do } \\
\text { AS-FOR }\end{array}$ & $\begin{array}{l}\text { Jankai, }_{\text {, }} \\
\text { John-GEN }\end{array}$ & $\begin{array}{l}\text { to } \\
\text { PART }\end{array}$ & $\begin{array}{ll}\text { on }_{\mathbf{i}} & w y j \\
\text { he } & \text { left }\end{array}$ & & $\begin{array}{l}d o \\
\text { to }\end{array}$ & $\begin{array}{l}\text { Londynu } \\
\text { London }\end{array}$ \\
\hline & \multicolumn{7}{|c|}{ "As for John, he left for London" (Tajsner 2015:45) } \\
\hline b. & $\begin{array}{l}\text { Co do } \\
\text { AS-FOR }\end{array}$ & $\begin{array}{l}\text { Jankai, } \\
\text { John-GEN }\end{array}$ & $\begin{array}{l}\text { to } \\
\text { PART }\end{array}$ & $\begin{array}{l}\text { widziałem } \\
\text { saw-1SG }\end{array}$ & $\begin{array}{l}\boldsymbol{g o}_{\mathbf{i}} \\
\text { him }\end{array}$ & $\begin{array}{l}w C z \\
\text { yest }\end{array}$ & \\
\hline
\end{tabular}

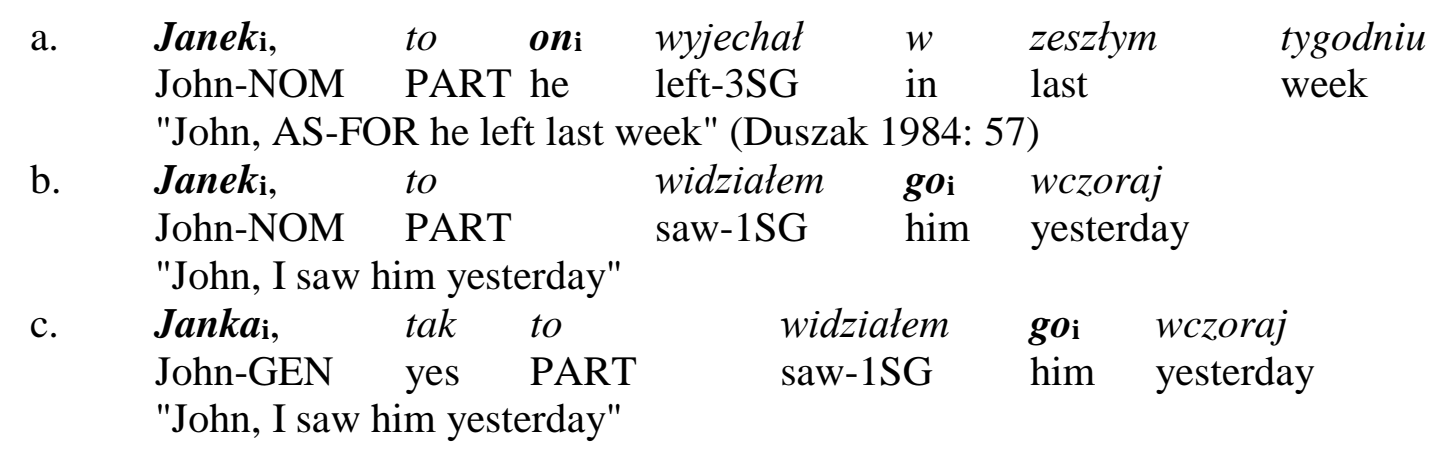

Even though the use of an overt resumptive pronoun in the matrix clause in Polish is well attested, as illustrated by the above examples, it is not obligatory. In fact, the resumptive element is often perceived as redundant and may be omitted (Duszak 1984: 58). This is especially pervasive in cases where the role of the dislocate corresponds to the subject of the matrix clause. It has been argued that in such instances the presence the resumptive pronoun or its absence does not have any bearing on the pragmatic interpretation of the expression. Consequently, two alternative LD structures are possible, i.e. LD with resumption and LD without resumption. The two are equivalent (Duszak 1984: 59).

For example, with respect to the 'as-for' type, the sentences (3.a) and (3.b) convey the same pragmatic information, reactivating a low-accessible referent and specifying its role. The presence or absence of the resumptive pronoun is optional: ${ }^{6}$

\footnotetext{
${ }^{4}$ It should however be noted that a pause can be long and evident or short and almost unperceivable. In general, a pause in Polish seems to be a gradient phenomenon that can contribute to the marking of LD in a more explicit or less explicit manner. Even though examples such as those in 1.a-b and 3.a-c commonly exhibit a pause, they can also be pronounced with a pause that is minimally perceivable or even without particular pausal intonation.

${ }^{5}$ Additionally, the dislocate is commonly definite: Te pytania, to one byty zbyt trudne 'These questions, they were too difficult' (Duszak 1984: 57; see also examples 5 and 7 below).

${ }^{6}$ The same applies to other 'constructions of this type: jeśli chodzi o..., jesli idzie o..., co się odnosi do...etc.
} 
(3)
a. Codo
Tomka,
to on o $_{\mathbf{i}}$ przyszedt
AS-FOR
Tom
PART he
came-3SG
"As for Tom, he has come"
b. Codo
Tomka,
to przyszedt
AS-FOR
Tom
PART came-3SG
"As for Tom, he has come"

If the matrix clause is an equative construction, the resumption (4.a) may be omitted if the predicative noun phrase is employed in the instrumental cases (4.b). In contrast, if the predicative noun phrase appears in the nominative, the absence of resumption seems to be less natural than its presence (4.c). However, a non-resumptive construction is still possible in certain circumstances (4.d).
a. Co do
Janka, to on
AS-FOR
John PART he is
harcerzem / harcerz
"As for John, he is a scout"
b. Codo
Janka,
to
AS-FOR
John
PART
jest harcerzem
is scout-INSTR
"As for John, he is a scout"
c. ?Co do Janka i, to jest harcerz
AS-FOR John PART is scout.NOM
"As for John, he is a scout" (compare Tajsner 2015: 41)
d. Co do
Jankai,
to jest ham
AS-FOR John PART is rude.person-NOM
"As for John, he is a rude person"

The 'simple' LD exhibits equivalent behavior, making it possible for the resumptive pronoun to be omitted. Once more, the two alternative variants express the same pragmatic function, thus being equivalent (Duszak 1984: 59).
a.
(Ten) Tomeki,
to on $\quad$ i $u \dot{z}$
przyszedt
(this) Tom
PART he already
came-3SG
"(This) Tom, he has come already"
$\begin{array}{llll}\text { b. } & \text { (Ten) Tomeki, } & \text { to juz } & \text { przyszedt } \\ \text { (this) Tom } & \text { PART already } & \text { came-3SG }\end{array}$
"(This) Tom, he has come already"

One should note that if the role of the dislocate is not the subject of the matrix clause - for instance if it is specified as a direct or indirect object, or as a prepositional complement - the resumptive pronoun must be specified overtly. This applies both to the 'as-for' (examples 6.ad) and 'simple' LD (examples 7.a-d) constructions.
a. Co do
Jankai,
to widziatem
goi
wczoraj
b. $\quad$ * Co do
John
PART saw-1SG
him
yesterday
AS-FOR
John
to widziałem
wczoraj
"As for John, I saw him yesterday"
yesterday 


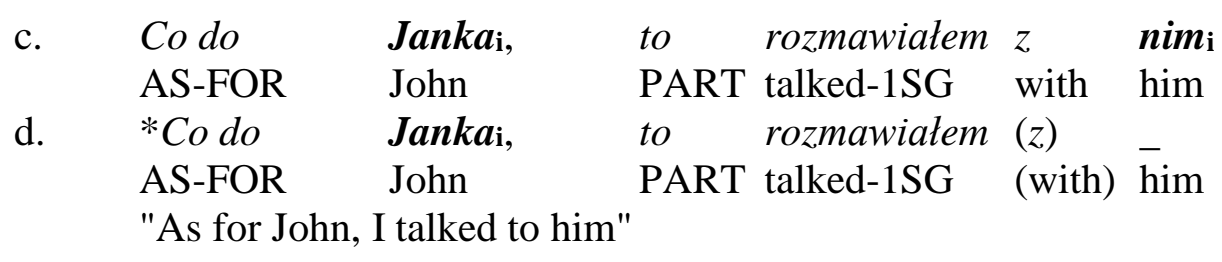

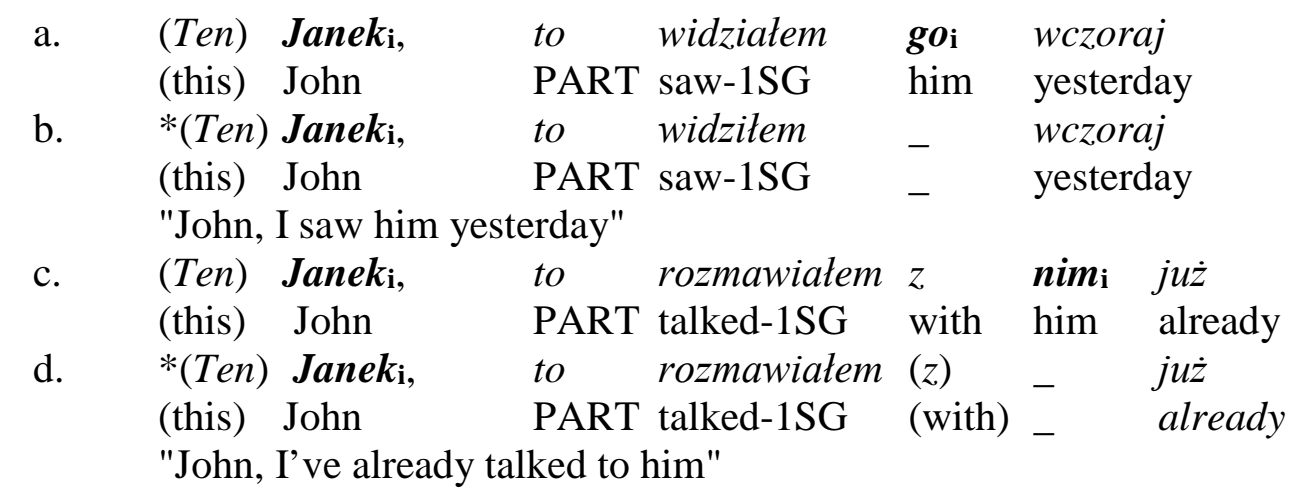

Nevertheless, if the dislocate of the 'simple' LD construction is not used in the casus pendens but rather assumes the case that is required by the matrix clause (see further below in this section), the resumption is not necessary (8.b and 9.d) even though it is possible (8.a. and 8.b):

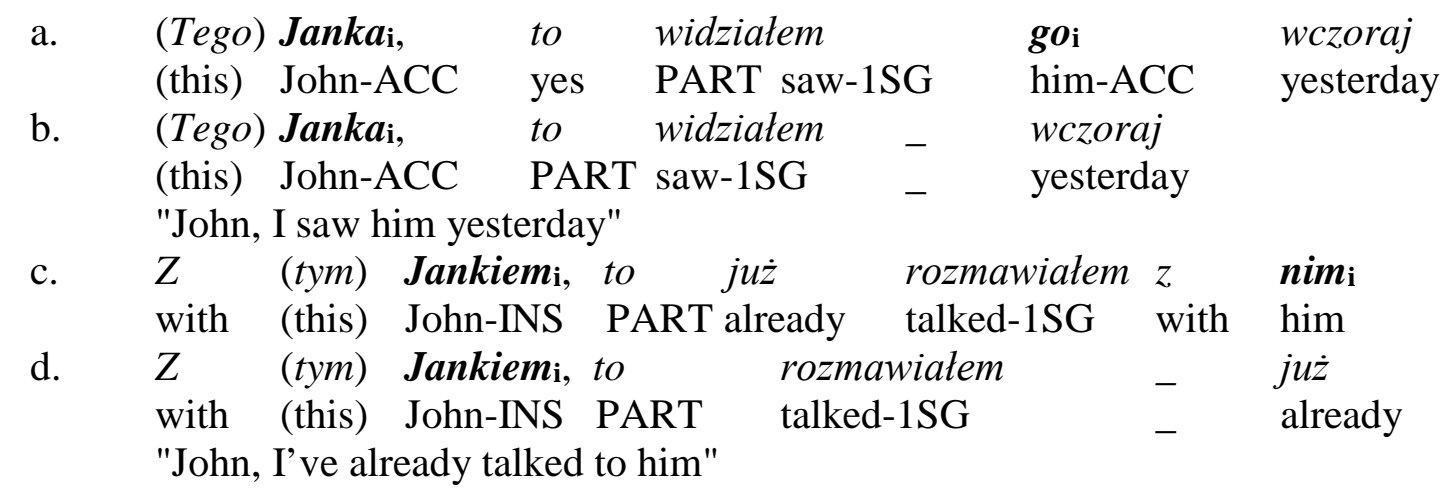

When employed in their canonical forms, the two types of LD constructions discussed in this section, are not common in standard written and/or spoken Polish (Duszczak 1984). First, the particle to tends to be omitted in written texts (Duszak 1984; Huszcza 1980, 1981) as its use has strong colloquial connotation, being typical of informal speech and dialects (Duszak 1984: 57; see also Paluszkiewicz 1971). Therefore, the sentences in (3.a), (5.a) and (8.a) are frequently reshaped into (9.a), (9.b) and (9.c), respectively.

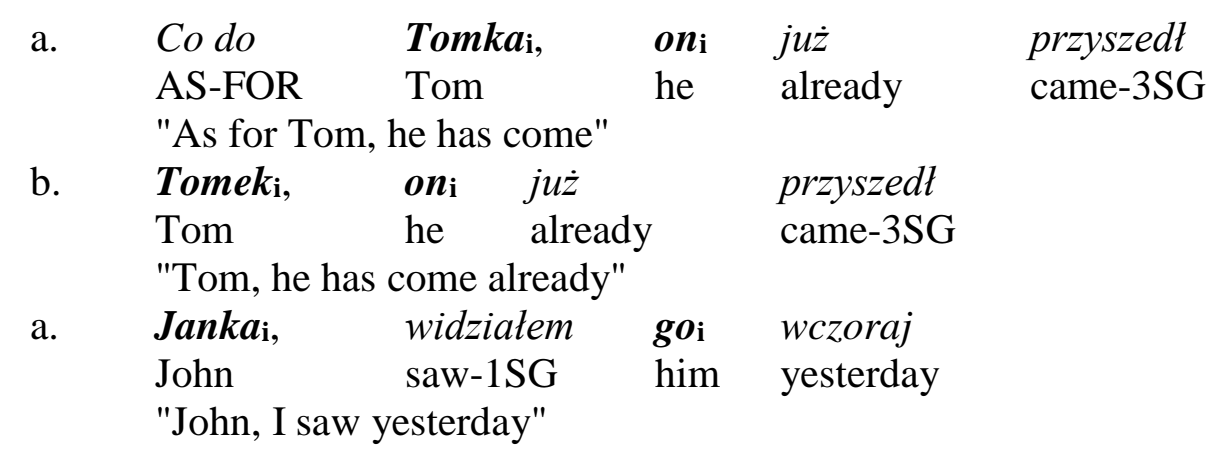


Second, the use of the casus pendens is highly unusual in Polish, both in written and spoken language. If the dislocate corresponds to an item whose role is not the subject of the matrix clause, speakers tend to inflect it in an appropriate case. Accordingly, the more common equivalent of (10.a) is the structure found in (10.b):

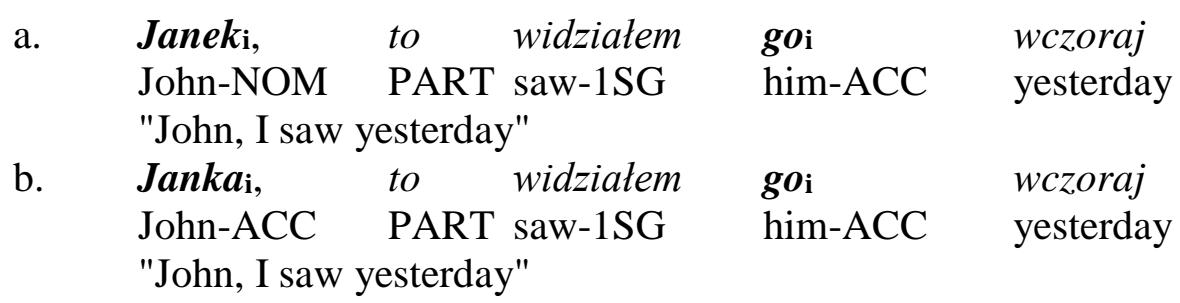

Third, the use of resumptive pronouns in the subject position (see examples 2.a and 5.a, introduced previously) is a characteristic of a colloquial language. It is rather undesirable in written texts, especially in those that belong to a higher and/or formal register (Paluszkiewicz 1971). In a similar vein, the use of resumption in instances where the dislocate fails to be employed as the casus pendens is not common in written language, being perceived as redundant. Since, as already explained, the casus pendens is a rare phenomenon in Polish, the overall commonness of resumption is low in LD constructions, especially in written texts.

If the particle to and the resumption are omitted, and the casus pendens is replaced by the appropriate case, the only feature that makes the construction an instantiation of a 'simple' LD is the phenomenon of pause. Thus, the example in (11.a) can be regarded as LD only due to the pausal intonation. Otherwise, it exhibits a morpho-syntactic structure that is equivalent to the unmarked word order. The same holds true for the example (11.b). It is only because of the pausal intonation that this sentence differs from Fronting (see Section 3). ${ }^{7}$ In the 'as-for' type, the particle to and resumption may also be omitted. However, the heading expression (e.g. co do) will distinguish this construction as LD from other structures (11.c) in addition to the pause.

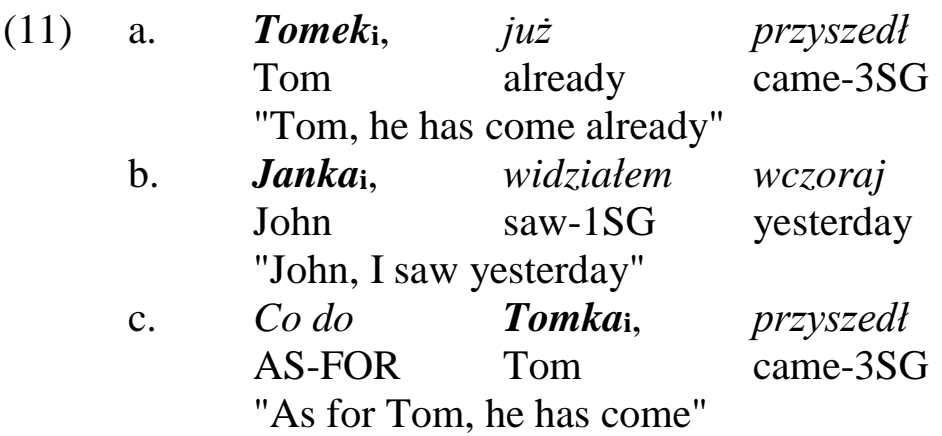

Overall, even though the various types of LD constructions in Polish frequently comply with the crosslinguistic prototype by exhibiting a resumptive pronoun in the matrix clause, the absence of resumption is more natural in certain instances. The two environments where the omission of resumptive elements is most typical are the following: a) an LD construction in

\footnotetext{
${ }^{7}$ The dislocated status of the constituent can still be determined by the position it takes in relation to other elements of the sentence. In particular, the dislocate precedes interjections (e.g. ah tak 'ah yes!': Tomek, ah tak już przyszedt and Tomka, ah tak już wudziałem), interrogatives (e.g. czy 'whether': Romek, czy już przyszedt? and Tomka, czy juź widziałeś?) and conjunctions (e.g. $\dot{z} e$ 'that': Powiedziat Janka ż już widziat; for a discussion of these syntactic characteristics from a crosslinguistic perspective, consult Westbury 2014, 2015).
} 
which the dislocate is identified as the subject of the matrix clause; and b) an LD construction in which the dislocate is not used as casus pendens but, instead, exhibits the case required by the matrix clause. The former structure applies both to the 'as-for' and 'simple' types of LD, whereas the latter only applies to the 'simple' LD.

\section{$2.2 \quad$ Performance-based evidence}

Having discussed properties of LD that emerge from the data provided by the native speakers of Polish, I will analyze the behavior of LD in a written corpus. Similar to most papers of this volume, this corpus is limited to renderings of the prototypical examples of LD in Biblical Hebrew, which constituted the starting point of the workshop. For the purpose of the present paper, 12 such examples were identified together with their three Polish translations: Biblia Gdańska (1632/2009), Biblia Tysiaclecia (1965/2003) and Biblia Polska UBS (1975). In total 36 instances of LD constructions were studied. ${ }^{8}$

There is only one case where an LD construction that is found in the Hebrew Bible would be translated in Polish by means of an 'as-for' LD type. No resumptive pronoun in used:

$$
\begin{aligned}
& \text { A co do oślici, [... nie trap się__i (1 Sam 9:20 B) } \\
& \text { and AS-FOR donkeys don't worry REFL }{ }^{9} \\
& \text { "As for your donkeys [...] give no further thought (to them) " }
\end{aligned}
$$

The 'simple' LD variety is by far the most common, being found in nearly all the remaining instances. Eleven times, the matrix clause employs a resumptive pronoun co-indexed with the dislocate. On five occasions, a personal pronoun is used (see examples 13 and 14.a-d). In one of such examples, as the personal pronoun co-indexed with the dislocate is the subject of the matrix clause, both the dislocate and the resumptive element stand in the nominative case:

$$
\begin{aligned}
& \text { Niewiasta }_{\mathrm{i}}[\ldots] \text { ona }_{\mathrm{i}} \mathrm{mi} \text { dała } \mathrm{z} \text { tego drzewa (Gen 3:12 A) } \\
& \text { woman me me gave from this tree } \\
& \text { "The woman, [...] she gave me from the tree" }
\end{aligned}
$$

The resumptive personal pronoun appears four times in a function other than the subject. It can act as a direct object (14.a-c) or a prepositional complement (14.d). In three examples, the dislocate exhibits the same case marking as the resumptive: genitive (14.a, c-d) or accusative (14.b). Only once, the dislocate appears in the Polish equivalent of casus pendens (the nominative), while the resumptive pronoun is marked by the genitive (14.c). ${ }^{10}$

\footnotetext{
${ }^{8}$ Two remaining cases that were also discussed in the workshop (namely, Gen 4:22 and 24:7) are omitted as they differ structurally from the other examples. In examples provided in this section, the three translations will be referred to by means of the following abbreviations: A (= Biblia Gdańska), B (= Biblia Tysiąclecia) and C (= Biblia Polska UBS).

${ }^{9}$ The absence of resumption may also stem from the fact that the Polish verb trapić sie may be employed intransitively (trapię się 'I am worried') in addition to the use in which a prepositional argument is required (trapię się o oślice 'I am worried about the donkeys').

${ }^{10}$ In Polish, direct objects exhibit a genitive case marking in negative constructions.
} 
(14)
a. A Lewityi, [...] nie opuścisz goi (Deut 14:27 A) and Levite not you.will.leave him
"And the Levite, [...] do not leave him"
b. I $\boldsymbol{z i e m i e ̨ i}_{\mathbf{i}},[\ldots]$ tobie jąi $\operatorname{dam}(\mathrm{Gen} 35: 12 \mathrm{~A})$ and the to.you it I.willgive
"And the land, [...] to you I will give it"
c. Oraz Lewita, [...] Nie opuścisz and Lewite not you.will.leave him
"And the Levite; You will not leave him"
d. Ale z drzewa $[\ldots]$, jeść $z \quad$ niegoi nie będziesz (Gen 2:17 A)
but from tree eat from it not you.will
"But of the tree, $[\ldots]$ you will not eat of it"

On one occasion, the resumptive element is a possessive pronoun (15). In that example, the dislocate is marked for the genitive in agreement with the possessive function of the resumptive pronoun. ${ }^{11}$

$$
\begin{aligned}
& \operatorname{Saraj}_{\mathrm{i},}[\ldots], \text { nie } \quad \text { będziesz zwat imienia jeji Saraj (Gen 17:15 A) } \\
& \text { Sarai not you.will call name her Sarai } \\
& \text { "As for Sarai [...]' you shall not call her name Sarai" }
\end{aligned}
$$

The remaining five cases employ a demonstrative pronoun as a resumptive element in the matrix clause. In all such instances, the dislocate is a relative clause introduced by the relative pronouns kto or który 'who'. The resumptive element invariably constitutes the subject of the matrix clause and is inflected in the nominative:

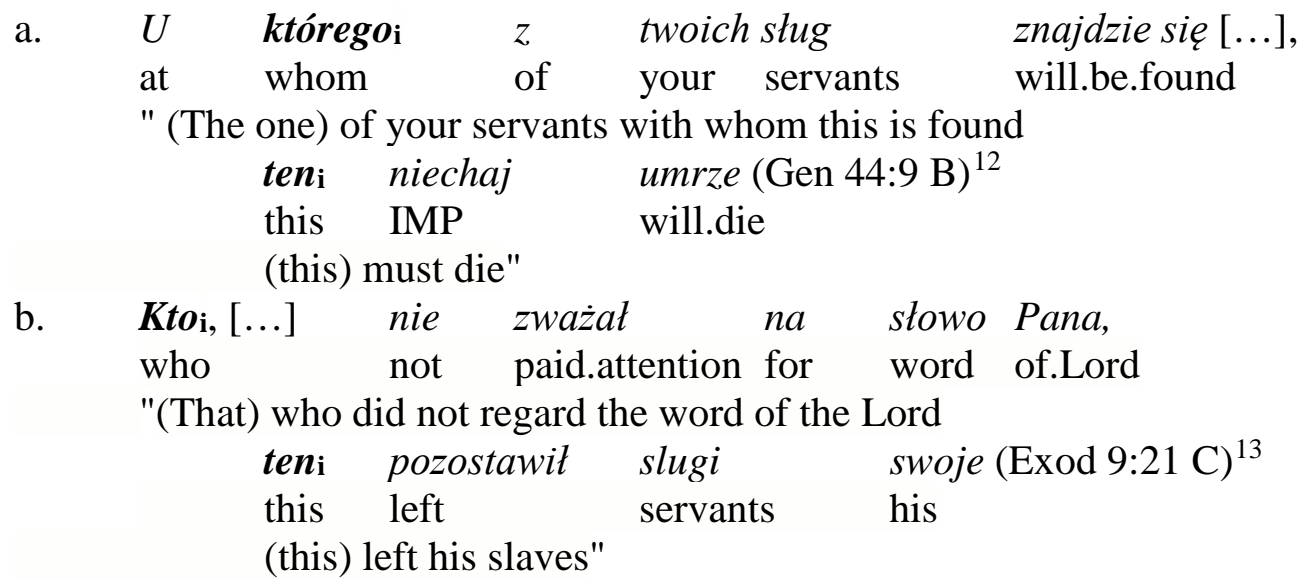

\footnotetext{
${ }^{11}$ The genitive case marking may also be interpreted as being imposed by the negative direct object of the verbal construction nie będziesz zwat 'you will not call'.

${ }^{12}$ See also U którego ze stug twoich by go znaleziono, ten niechaj umrze (Gen 44:9 C). Even though in these examples, the relative pronoun stands in the genitive case (imposed by the proposition $u$ 'at, by, with'), the whole clause, which it introduces, can be viewed as in the nominative, that is, with a demonstrative pronoun (e.g. ów 'that') implied but unexpressed.

${ }^{13}$ See also Ale kto nie przylożyt serca swego do stowa Pańskiego, ten zostawit stugi swe (Exod 9:21 A).
} 


c. Lecz któryi wynijdzie z żywota
but who will.go.out from life
"(The one) who will be brought forth by you
ten będzie dziedzicem twoim (Gen 15:4 A)
this will.be heir
(this) will be your heir"

It should be noted that all the examples analyzed thus far, when pronounced, use a pausal intonation, which is marked in the text by a comma. ${ }^{14}$

The twenty-two cases where the LD structures found in the Hebrew original are rendered, in Polish, by means of constructions that could be viewed as the 'simple' LD with no resumption. As such constructions also fail to use the particle to, they are almost indistinguishable from Fronting or, in some instances, from an unmarked word order (see further below in this section; refer also to Section 3). However, their discourse pragmatic function in terms of information structure (i.e. (re)activation of a low-accessible referent), their detachment from the matrix clause, well-marked pausal intonation, and the possibility of using to in conversational variants warrant their interpretations as non-canonical instances of LD.

In seventeen instances, the dislocate is marked for the case other than nominative, thus failing to be used in the casus pendens. The specific marking is determined by the matrix clause and corresponds to the role (and the case) of the resumptive element if this was expressed. This role can correspond to a direct object (17.a-d) or a prepositional complement (17.e-g). This type of constructions is similar to Fronting, being distinguished from it only by the pause and prosody (see section 3).
a. Ziemię, [...], oddaję tobie i land I.give to.you and your offspring
twemu potomstwu $\left(\right.$ Gen 28:13 B) ${ }^{15}$ "The land, [...] I am giving (it) to you and your offspring"
b. Kraj, daje
land, [...] I.give to.you tobie $\left(\right.$ Gen 35:12; B) ${ }^{16}$
"The land [...] I am giving (it) to you"
c. Caty ten kraj, [...], daje tobie (Gen 13:15 B) ${ }^{17}$ all this land I.give to.you
"All the land [...] I am giving (it) to you"

$\begin{array}{lllll}\text { d. } & \text { Saraj, [...] } & \text { nie } & \text { będziesz nazywal } & \text { Saraj (Gen 17:15 C) }{ }^{18} \\ & \text { Sarai } & \text { not } & \text { you.will call } & \text { Sarai }\end{array}$

\footnotetext{
${ }^{14}$ Additionally, in colloquial speech, all these examples would naturally lend themselves towards the use of the particle to, e.g. Co do oślici, TO nie trap się o nie (cf. example 12), Ziemięi, TO tobie ja $\boldsymbol{q}_{\boldsymbol{i}}$ dam (cf. example 14.b) and Któryi wynijdzie z żywota twego TO ten będzie dziedzicem twoim (cf. example 16.c). However, due to the colloquial nature of the particle to, this item is typically absent in written texts, especially of a higher register such as biblical translation.

${ }^{15}$ See also ziemię tę, na której ty śpisz, tobie dam i nasieniu twojemu (Gen 28:13 A); Ziemię, na której leżysz, dam tobie i potomstwu twojemu (Gen 28:13 C).

${ }^{16}$ See also A ziemię, która dałem Abrahamowi i Izaakowi, dam tobie (Gen 35:12 C).

${ }^{17}$ Wszystkę bowiem ziemię, która ty widzisz, dam tobie, i nasieniu twemu aż na wieki (Gen 13:15 A); Bo cała tę ziemię, która widzisz, dam tobie i potomstwu twemu na wieki (Gen 13:15 C).

${ }^{18}$ See also Żony twej nie będziesz nazywat imieniem Saraj, lecz imie jej będzie Sara (Gen 17:15 B).
} 


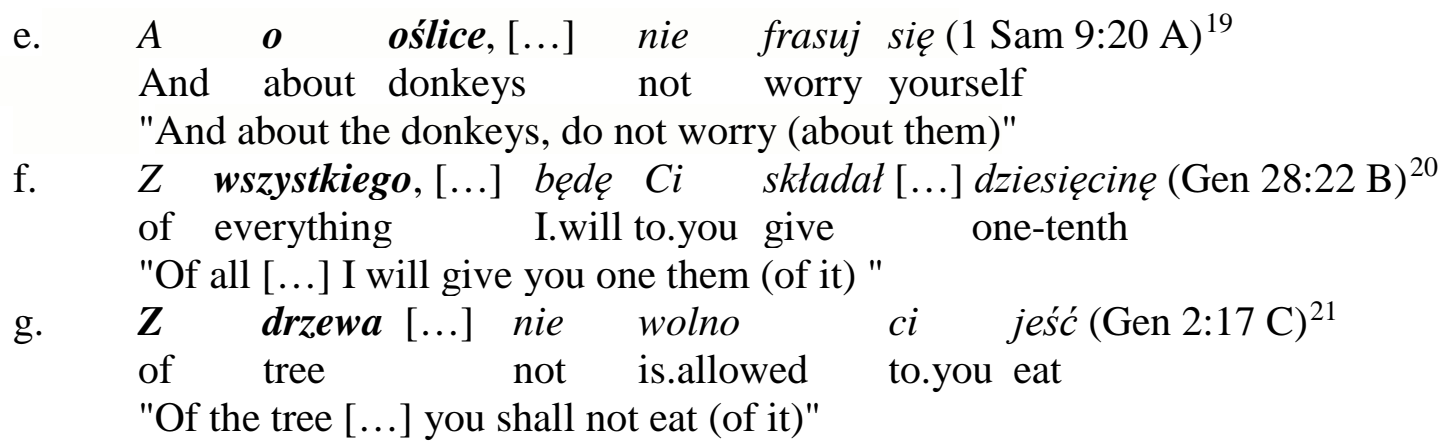

Five times, the dislocate coincides with the subject of the matrix clause and is marked for the nominative. ${ }^{22}$ In two cases, the dislocate is a noun (18.a). Once, it is a demonstrative pronoun (18.b). In two further instances, it is a relative pronoun (18.c-d). ${ }^{23}$ All these constructions strongly resemble an unmarked word order (namely, subject + verb), only differing from it by exhibiting the pausal intonation.

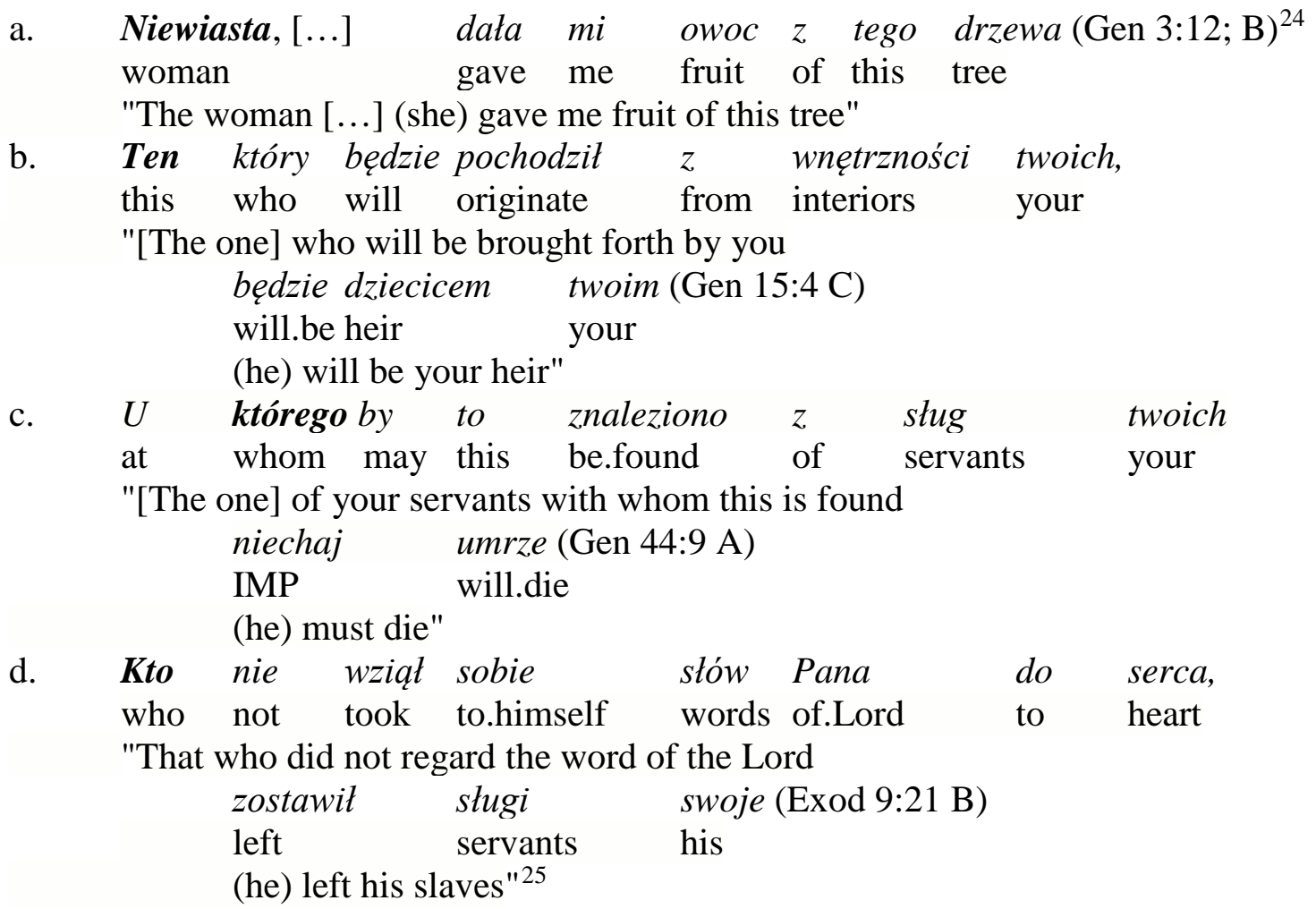

\footnotetext{
${ }^{19}$ See also O oślice zaś, [...] nie troskaj się, gdyż znalazty się (1 Sam 9:20 C).

${ }^{20}$ See also a ze wszystkiego, co mi dasz, dziesięcinę pewnq oddawać ci będę (Gen 28:22 A); i ze wszystkiego, co mi dasz, będę ci dawat doktadnie dziesięcinę (Gen 28:22 C).

${ }^{21}$ See also ale $\mathbf{z}$ drzewa poznania dobra i zła nie wolno ci jeść (Gen 2:17 B).

${ }^{22}$ In example (15.c), the relative pronoun $u$ którego 'with/by whom' (which stands in the genitive case) makes reference to the nominative form of an implied (albeit unexpressed) demonstrative pronoun ten 'this (one)'.

${ }^{23}$ Lastly, in two cases, no LD structure (even highly non-prototypical) can be detected: Nie opuścisz też lewity, który jest w twoich murach, bo nie ma on działu ani dziedzictwa z toba (1 Deut 14:27 B); Nie on będzie twoim spadkobierca, lecz ten po tobie dziedziczyć będzie, który od ciebie będzie pochodzit (Gen 15:4 B).

${ }^{24}$ See also Kobieta, która mi dateś, aby była ze mna dała mi z tego drzewa i jadtem (Gen 3:12 C).

${ }^{25}$ In more colloquial speech, the two types discussed in examples (17) and (18) can be reshaped into the following more explicit LD structures where the particle to and a resumptive element are employed: Ziemięi, [...] TO jąi
} 
Overall, Polish uses a variety of constructions to render the LD found in the Biblical text. The 'simple' LD is by far more common than the 'as-for' type. The feature that is most persistent in all variants is the pausal intonation. By contrast, the particle to is never used, as it would render the translation excessively colloquial. As far as the resumption is concerned, even though this feature is found in various cases, its omission is more common. Accordingly, the frequent omission of resumptive elements in translations is consistent with previous observation recognizing the optionality of resumption in LD constructions and, de facto, its common absence in Polish.

\section{Discussion - Left Dislocation and Fronting}

The evidence presented in the previous section indicates that various features that can mark a given construction as LD are not compulsory in Polish. The presence of resumption is optional and often perceived as redundant or undesirable, the use of casus pendens is highly uncommon being rather replaced by appropriate inflectional form, and the particle to is infrequent outside of colloquial registers. It is only pausal intonation (or a comma) that consistently appears in LD structures.

This possible omission of certain characteristics means that the distinction between Fronting (sometimes referred to as 'topicalization proper') and LD is blurred in certain circumstances in Polish (Duszak 1984: 56) ${ }^{26}$ Especially in written texts, the two constructions can be levelled (Duszak 1984: 60, 68). In fact, if the phonetic features such as the pause are disregarded the two structures may be identical (Duszak 1984: 58). Inversely, the same construction can afford for two interpretations, i.e. as LD and as Fronting (Duszak 1984: 60). Accordingly, a form that could be a canonical instantiation of LD is often transferred into a structure that is more similar to Fronting, not because the function of a given expression changes, but rather because of language-specific idiosyncrasies (Duszak 1984: 68). In general, the less prototypical and iconic a given LD construction is, the more propitious it is to formally overlap with other categories (e.g. Fronting) and to be used for other grammatical purposes (e.g. focus and topicalization).

As a result, rather than constituting two separate phenomena, LD and Fronting are connected and form a gradient (Duszak 1984: 59-61, 68). This is especially evident for the 'simple' LD construction in which the dislocate is not marked by any overt heading expression in contrast to the 'as-for' type. If the dislocate coincides with the subject of the matrix clause, the following cline linking the LD prototype to Fronting and/or further to the unmarked word order can be proposed (see Duszak 1984: 59). In the LD prototype, the dislocate is separated from the matrix by a pause and the particle to. It is also co-indexed with the resumptive element. As one or more features are omitted, the construction becomes less canonical till it reaches the stage where it is only the pausal intonation that differentiates it from Fronting and/or the unmarked word order.

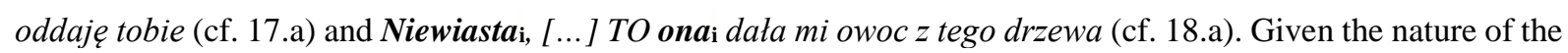
translation, that is its higher register, the particle to is not used as it triggers strong colloquial associations.

${ }^{26}$ Another contributing factor may be the relatively flexible word order in Polish (Duszak 1984: 68). 


\begin{tabular}{|c|c|c|}
\hline Construction & Examples & Features exhibited \\
\hline \multirow[t]{3}{*}{ LD prototype } & Janek, to on chyba oszalat & $\begin{array}{ll}\text { - } & \text { pause } \\
\text { - } & \text { resumption } \\
\text { - } & \text { particle to }\end{array}$ \\
\hline & Janek, on chyba oszalat & $\begin{array}{ll}\text { - } & \text { pause } \\
\text { - } & \text { resumption }\end{array}$ \\
\hline & Janek, to chyba oszalat & $\begin{array}{ll}\text { - } & \text { pause } \\
\text { - } & \text { particle to }\end{array}$ \\
\hline & Janek, chyba oszalat & - $\quad$ pause \\
\hline Fronting & Janek! chyba oszalat & - $\quad$ focal/topical intonation ${ }^{27}$ \\
\hline Unmarked word order & Janek chyba oszalat & $\begin{array}{ll}- & \text { unmarked intonation }\end{array}$ \\
\hline
\end{tabular}

Table 1: Cline from Left Dislocation to Fronting (the subject type)

The cline for $\mathrm{LD}$ in which the dislocate is related to a role other than the subject is more complex. This principally stems from the fact that the dislocate may stand in the casus pendens. If the role of the dislocate corresponds to the subject, a possible casus pendens is undistinguishable from the nominative. Once more, the cline links the prototype of LD with Fronting. At the pole of the LD prototype, four features mark a given form as LD: casus pendens, pause, resumption and particle to. At the pole of Fronting, no one of them is found. The least canonical shape of LD is again a construction in which only pausal intonation would be present - all other morphosyntactic features being identical to Fronting (see Table 2 below).

\footnotetext{
${ }^{27}$ The particle to is also possible in Fronting. The topical and/or focal intonation is necessary to clearly distinguish Fronting from unmarked sentences. Thus, the same morpho-syntactic structure (Janek chyba oszalal) can offer three functions depending on its intonation: pausal (LD), topical/focal (Fronting) and unmarked (unmarked word order). As already mentioned, pause is also a gradient phenomenon. Accordingly, in more prototypical LD constructions, pause is clearly visible. However, as an LD construction approximates the prototype of Fronting or unmarked word order, pause becomes shorter.
} 


\begin{tabular}{|c|c|c|}
\hline LD prototype & Janek, to chyba go znam & $\begin{array}{ll}\text { - } & \text { casus pendens } \\
\text { - } & \text { pause } \\
\text { - } & \text { resumption } \\
\text { - } & \text { particle to }\end{array}$ \\
\hline & Janek, chyba go znam & $\begin{array}{ll}- & \text { casus pendens } \\
\text { - } & \text { pause } \\
\text { - } & \text { resumption }\end{array}$ \\
\hline & Janka, to chyba go znam & $\begin{array}{ll}\text { - } & \text { pause } \\
\text { - } & \text { resumption } \\
\text { - } & \text { particle to }\end{array}$ \\
\hline & Janka, chyba go znam & $\begin{array}{ll}\text { - } & \text { pause } \\
\text { - } & \text { resumption }\end{array}$ \\
\hline & Janka, to chyba znam & $\begin{array}{ll}\text { - } & \text { pause } \\
\text { - } & \text { particle to }\end{array}$ \\
\hline & Janka, chyba znam & - $\quad$ pause \\
\hline Fronting & Janka! chyba znam & $\begin{array}{ll}\text { - } & \text { focal/topic intonation }{ }^{28} \\
\text { - } & \text { movement }\end{array}$ \\
\hline
\end{tabular}

Table 2: Cline from Left Dislocation to Fronting (the “non-subject” type)

In contrast, the 'as-for' type of LD, is always distinguished from Fronting through its morphosyntactic structure, even though the resumptive element and the particle to are omitted. That is, a heading expression such co do will invariably mark it as LD. In these types of LD constructions, the pausal intonation is likewise regularly preserved. ${ }^{30}$

\section{Conclusion}

The present paper studied properties of LD constructions in Polish, focusing on the presence (or absence) of resumption. Both the evidence provided by native speakers and the data extracted from the corpus show that, in various cases, resumption is not obligatory in Polish. In fact, Polish LD constructions omit resumptive elements more commonly than they employ them. The absence of resumption is a part of a more a general phenomenon - the gradient nature

\footnotetext{
${ }^{28}$ The use of the particle to is also possible.

${ }^{29}$ Fronting for topical and focal functions can also be found in other positions, in which an element is actually not fronted. All such cases are morpho-syntactically distinct from LD. Thus, Fronting in Tables 1 and 2 only refers to one of the possible topicalization/focus constructions in Polish (Duszak 1984).

${ }^{30}$ This gradient nature of LD in Polish is consistent with findings presented in two other papers included in this volume that analyze LD constructions in Arabic (Andrason 2016) and Xhosa (Andrason and Visser 2016). As demonstrated in these studies, in Arabic and Xhosa, certain varieties of LD are formally identical or highly similar to Fronting to the extent that the two forms overlap. As argued in these papers, it is pausal intonation that seems to be the most persistent characteristic of LD, while resumption fails to be necessary even though it is commonly used.
} 
of LD constructions ranging from more canonical (similar to the crosslinguistic prototype) to less canonical (more distant from the prototype), and their relation to Fronting.

To conclude, this article provides further support for regarding resumption as non-obligatory for LD to occur. Therefore, constructions that convey the function typically associated with LD (i.e. (re)activation of a referent that is characterized by a low degree of accessibility and identification of this referent's role) but lack resumption can and should be regarded as cases of LD. Given the gradient nature of LD and the prototype effect of grammatical categories, there is no need to postulate a new category of 'extreme topicalization' for such "nonresumptive” LD expressions. Rather, as convincingly argued by Westbury (2015) LD is a radial category (see Andrason, Westbury and van der Merwe 2016, Westbury 2016). That is, a canonical form of LD should be proposed - a form with which various constructions may comply to a greater or lesser extent. One of such less canonical examples would be an LD with no resumptive element. In any case, the sole absence of resumption does not justify the classification of $\mathrm{BH}$ constructions - that otherwise comply with the LD prototype - as a different category.

\section{References}

Andrason, A. 2016. Left Dislocation in Arabic: The complexity of form and meaning. Stellenbosch Papers in Linguistics Plus 50. 111-138.

Andrason, A. and M. Karani. forthcoming. Syntactic gradience: The non-resumptive Left Dislocation in Arusha (Maasai). Studia Linguisticae Universitatis Iagellonicae Cracoviensis.

Andrason, A. and M.W. Visser. 2016. The mosaic evolution of Left Dislocation in Xhosa. Stellenbosch Papers in Lingusitics Plus 50. 139-158.

Andrason, A., J. Westbury, C.H.J. van der Merwe. 2016. Left dislocation: An exploration in linguistic typology. Stellenbosch Papers in Linguistics Plus 50. 1-20.

Biblia Tysiaclecia Online. 1965/2003. Poznań: Wydawnictw Pallottinum.

Biblia Gdańska. 1632/2009. Available at www.wordproject.org/bibles/pl/index.htm

Biblia Polska UBS. 1975. United Bible Society.

Bondaruk, A. 2013. Copular Clauses in English and Polish: Structure, Derivation, and Interpretation. Lublin: Wydawnictwo KUL.

Citko, B. 2008. Small clauses reconsidered: Not so small and not all alike. Lingua 118(3). 261295.

Duszak, A. 1984. Topical sentence positions in English and Polish. Papers and Studies in Contrastive Linguistics 18: 55-70. 
Holmstedt, R. 2014. Critical at the Margins: Edge Constituents in Biblical Hebrew. KUSATU Kleine Untersuchungen zur Sprache des Alten Testaments und seiner Umwelt 17. 109-156.

Huszcza, R. 1980. Tematyczno-rematyczna struktura zdania w języku polskim. Polonica 6. 5771.

Huszcza, R. 1981. Tematyczno-rematyczna struktura zdania w językach różnych typów. $\mathrm{PhD}$ dissertation, University of Warsaw.

Paluszkiewicz, M. 1971. Podwajanie podmiotu - osobliwość języka mówionego. Język Polski 51. 14-21.

Rutkowski, P. 2006. From demonstratives to copulas: A cross-linguistic perspective and the case of Polish. Journal of Universal Language 7. 147-173.

Tajsner, P. 2015. On specification predication and the derivation of copular to-clauses in Polish. Studia Anglica Posnaniensia 50(4). 25-66.

Tajsner, P. forthcoming. On focus marking and predication. Evidence from Polish with some notes on Hausa. Lingua Posnaniensis.

Van der Merwe, C.H.J. and J. Naudé (forthcoming). Biblical Hebrew Reference Grammar.

Westbury, J. 2014. Left-Dislocation in Biblical Hebrew: A Cognitive Linguistic Account. PhD dissertation, Stellenbosch University.

Westbury, J. 2015. Left dislocation in Biblical Hebrew: Towards a comprehensive syntacticosemantic and discourse-pragmatic profile. Talk at the SBL Conference, Atlanta (Georgia), 23 November, 2015.

Westbury, J. 2016. A Functional Profile of Left Dislocation in Biblical Hebrew. Stellenbosch Papers in Linguistics Plus 50. 65-90. 